\title{
UNDERSTANDING CASTE WITH ITS RELATIVES
}

\author{
Sri Akhil Chandra Borah \\ M.A, M.Phil. in Political Science, Dibrugarh University, Assam, India
}

\begin{abstract}
In traditional Indian societies, the Caste system is seen as an agency of social stratification. On the basis of the Caste system, the people in Indian societies are categorised as-Brahmin, Kshatrya, Vaishya and Sudra. Thus, the Caste is considered as a dominating system in Indian societies, especially among the Hindus. In understanding caste, an ambiguity is seen that people usually use the two termsVarna and Jati interchangeably to refer the caste system. But these two terms has their specific meaning. Therefore we can't interchangeably use these two terms. Hence, this article is an attempt to break the ambiguity between the, varna and jati. Moreover, we can't properly understand the Caste, alienating it from its relatives with whom the caste keeps intimate relation. Further, the relatives with whom it interacts, made the caste a perpetuate one in Indian societies by reproducing the same. Hence, this article is an attempt to understand the caste with its relatives such as-Endogamy, Division of work, Punishments, the ideology of purity and pollution and Gender.
\end{abstract}

Key words: Caste, Varna, Jati, Endogamy, Division of Work, Punishments, Purity and Pollution, Gender

Cite this Article: Sri Akhil Chandra Borah. Understanding Caste with its Relatives, International Journal of Management, 11(12), 2020, pp 1882-1889.

http://iaeme.com/Home/issue/IJM?Volume=11\&Issue=12

\section{INTRODUCTION}

Oxford Advances Learner's Dictionary defined the caste as a system of dividing society into classes based on differences in family origin, rank or wealth. But in traditional Brahminical texts, two terms- 'Varna' and 'jati' are used to refer the caste system in order to classify the society. In other words these two words are used synonymously to indicate the caste system. But we can't use these two words interchangeably because according to the sociologists they suggest different meaning. The word 'varna' implies the four divisions of the society as depicted by the brahminical scriptures. These four varnas are- Brahmana, Kshatriya, Vaishya and Sudra. On the other hand 'jati' is a group of people characterised by the principle of 'endogamy'. Means the people of that particular group must marry within the group only. The people who are the member of a jati are always a member of a descent group. Further, 
traditionally the jatis are allocated specific profession, cultural practices such as food, dress and rituals. Thus both the terms varna and jati suggests different meaning and hence we can't use these term interchangeably with the word 'caste'. Indeed, caste is a specific and unique scale of social stratification that includes various hereditary groups of people or jatis (Chakravarti, 2013).

The words- varna and jati has multiple meanings therefore people fall into confusion while using these two words. Many scholars uses the term varna to indicate colour and they find its origin in the difference between the fair Aryas and dark indigenous people. But in the early sacred literature varna was used to mean a hierarchical order. The hierarchical order of the society is represented by the four varnas and each varna encompasses a particular group of people. But varna is not confined within the human society only. Therefore varna is problematic to use only in the context of human being as N.K Bose argued that land and temples are divided into four varnas. Moreover the varna division is very rigid as it suggests an exclusive and exhaustive order because apart from these four varnas there will not emerge other varna. In other words in the varna order encompasses all the human being. Like the word Varna, Jati has been using to indicate the caste system from long time. But the difference between varna and jati is lies into their capacity of inclusiveness. The term jati refers more units of human being that formulated the caste system. Jati don't suggest any means for the stratification of the society as varna do. Further jati is not exclusive as the varna because it is accommodative in nature (Beteille, 1996).

The caste system has close relationship with the marriage principles. In the context of caste society marriage principles are the matter of strict observation. Because marriage is the only way through which a particular caste can be maintain and reproduced. It is the endogamous marriage principle which is prescribed and encouraged by the caste society and its law. Exogamous marriage principle or practice is strictly prohibited in the caste ridden society as it is a threat toward the caste system. Therefore between these two marriage principles, endogamy is the desired in order to reproduction of the caste system. Hence, endogamy is regarded as the only peculiar feature of the caste system. Moreover it can be said that endogamy and the caste are the two sides of a same coin because imposition of endogamy over the exogamy implies the creation of the caste system (Singh, 2011). Therefore the importance of the endogamy in the caste system is very obvious that without this the caste system would be demolished or stagnant. To give a continuous flow to the caste system or transmit the same to the next generation the members of this system must have endogamy marriage as the membership of the caste system can only come from the birth (Quigley, 1999).

A particular caste includes various jatis in its boundary. As the jati implies a bounded group of people having some peculiar characteristics that make that particular jati separate from other jatis. Therefore to maintain the specialities of the jati, it is important to keep separate from other jatis. But it is possible only through the endogamous marriage system as endogamy implies the marriage practice of two people within their bounded group of people only. As marriage is the only sanctioned way of procreating the children therefore the marriage is seen as very normative in the context of Indian caste society. The caste system and the immortality of the male line are rest on the marriage practices therefore marriage is the easy way to transfer the paternal caste to his children. Hence in caste society endogamous marriage practices is regarded as the only desirable marriage principle through which the caste of the father could be transfer to his offspring. To enforce the endogamous marriage practice the caste society only encourage the arranged marriage among the members of a particular caste or jati because it is the manifestation of the principle of endogamous marriage 
while the love marriage is regarded as the threat to one's caste or jati. Because in love marriage there is less chance to follow the caste norms (Chakravarti, 2013).

Endogamy is the key to chopped off a vast population into a bounded group of people i.e. caste with some specific features. Therefore caste can be propagated or proliferate through the system of endogamous marriage practice. But the maintenance of the endogamy is not an easy process. Many means are therefore applied in preserving the endogamy against exogamy. First of all the conjugal right of the couple must give within the group of people from which that couple belongs. This is not the ultimate means of preserving the endogamy. But from this point the responsibility of the caste society increases in protecting the endogamy because the life of the married couple doesn't end together. Therefore surplus men (widowers) and surplus women (widows) emerge in the caste society. Hence it became more difficult to maintain endogamy over the surplus men and surplus women because they are regarded as the potential danger to the caste society. In the case of the surplus women the process of the imposition of the endogamy is more difficult than the surplus men because earlier in Indian caste society Sati was practised over the widows i.e. a peculiar Indian innovation in controlling women's sexuality. But Sati was legally prohibited in India. Therefore the only way is remained to impose endogamy over the surplus women that a widow must remain as widow throughout her rest of life from the very beginning of her widowhood. It is not only in the phase of widowhood that the principle of endogamy is imposed or maintained. In the Hindu caste society the Protloma (Hypogamy) prohibited. According to the Hypogamous marriage principle marriage is taken place between the high caste women and low caste man. Therefore to restrict the hypogamous marriage, women's sexuality is controlled through institutionally (Chakravarti, 2013). Not only the hypogamous marriage but also the marriage between the high caste men and low caste women is not sanctioned in the Hindu caste society. Therefore an institutional arrangement is required to prevent such marriage practices. As this research work is done in the context of Assamese society hence in this regard I have discussed the role of Assamese socio-political institutions such as the Namghar and the Satras in the third chapter of this research work.

Like the widows, in the case of the widowers the process of the imposition of endogamy is different from the surplus women i.e. the widows. Because as the society did earlier in case of the widows could not applied for the widowers for instance the widowers could not burnt alive with the dead body of their wives because being men they are the sturdy soul of the caste society and men are regarded as the asset of the patriarchal society. Therefore the surplus men or the widower were not burnt along with their dead wives in early Indian caste society. But it is necessary to impose endogamy over the widowers and one path is for open for this that is imposition of celibacy over them. But it is also not correct way of imposing endogamy because this path will take by those widowers who are pious in their outlook. Therefore imposition of celibacy is not the safe way to maintain the endogamy. Under such situation one more way is remain to impose endogamy over the widowers that they should get wed with the marriageable girl within his caste. Therefore it can be said that the caste society tries to maintain and impose endogamy to ensure their caste (Rodgigues, 2017).

Though endogamy is the key stone of the caste society in order to maintain and ensuring the caste system, applying rigid and cruel punishment or putting over emphasise on the endogamous marriage norm is the reason of the decline of the endogamy and subsequently the caste itself. People are given exemplary punishment that goes for the exogamous or intercaste marriage in the society. Even it is seen that the inter-caste married couple are given death penalty in the North Indian states like Haryana (Panini, 2001). In Haryana it is seen that the lack of marriageable girl due to the hyper imposition of endogamy and killing of girl child leads their male counterpart to marry with the girl of neighbouring states of different castes 
(Abraham, 2014). It is proved that marriageable girls are borrowed from the states like Assam to Haryana for marriage purpose (Khan, 2012) whose castes are not similar to that of the people of Haryana. Thus along with the violation of the human rights, over stress on endogamy leads to its decline and subsequently the rigid caste system may dilute automatically.

Though, it is seen that the over emphasise on the endogamy leads to the decline of endogamy and caste system itself but it is evident that the Hindu caste society tries to maintain the same. It is already mentioned above that various socio political institutions have been taking the responsibility of maintaining the endogamy and the caste system. In the process of maintaining the endogamy and caste system the socio-political institutions go through the help of certain punishment mechanism. In North Indian state like Haryana, it is seen that the Khap Panchayat plays a vital role. The people who violates the prescribed marriage role, they are punished by the Khap Panchayat. 'Hukka-pani bandh karna' (excommunication), imposing heavy fine or penalty are common punishment in Haryana. The most violent form of punishment is seen as Honour Killing in Haryana which is decided by the Khap panchayat as punishment of infringement of marriage rule of their society. Not only inter-caste marriage is regarded as punishable crime but inter-caste love is also a violation of caste rule in Haryana.

Like the societies of Haryana, in the Assamese society the socio-political and religious institutions such as the Namghar and the satras are seen as the protector of the endogamy and the caste system. In this process these institutions relies on various punishments if someone of the society tries to violate their rules and regulations. Apart from these two institutions, the family which is a universal institution is seen as the main propagator of the caste system and endogamy. The family is the chief institution that socialized the caste system and the endogamous marriage principle among the people of caste society. In many times it is seen that the family coercively imposed these casteist rules on the family members. In the fourth chapter of this research work, an attempt is made to analyse how the Assamese socio-political institutions- the Namghar and the Satra including the family punished the people who infringes the caste rule in propagating the caste system in love.

Two ideologies- purity and impurity and division of work are closely associated with the caste system. As above mentioned that the caste system is a scale for the classification of the people into various groups in caste society. The scale measures the intensity of the purity of the people and accordingly they are ranked in a hierarchical order. The level of purity of the people rests on their traditional occupation. Traditional occupation here implies the profession of the people of the caste society which are allotted to them by birth. For instance the Brahmanas are assigned to study and teach, to sacrifice, and to give and take gifts. Likewise the Ksatriya are allotted to the work of protecting the people from the war or external threat. Further they can sacrifice and study like the Brahmins. The Vaishy's fundamental function is to bring up the cattle, to pursue trade and lend money. Finally the Sudra's are allotted the duty of assisting their higher classes- Brahman, Ksatriya and Vaishya. Moreover the Sudras are assigned to the duty of cleaning the death bodies according to the brahminical literatures such as Rig Veda. This epigram is beautifully depicted in the Bhagaavad Gita too that each man has a place in their society and they have their specific works or functions and these should be effectively performed by them (Quigley, 1999). Here a question arises that how the notion of purity and impurity or pollution related to the occupations of the people. The answer is rests on the formations of the varna. According to the theory of the formation of chaturbarna i.e. four varnas, each varna are sprung from the different body parts of a supreme man. The theory says that the Brahmins are emerged from the mouth of that primeval man. Likewise, Ksatriyas, Vaishyas and Sudras were created from the shoulder, thigh and feet respectively. 
Thus according to the body part the level of purity is counted. For instance the mouth is regarded as more superior than the feet and hence the Brahmin who is emerged from the mouth of the primeval man is regarded as having high level of purity than the people who were created from the feet i.e. the Sudras of that supreme man. Likewise in the caste hierarchy the four varnas are placed according to the level of purity. Therefore it is seen in the hierarchy of caste that the Brahmins are at the apex and the Sudras are at the bottom of the caste hierarchy. This is the reason that in the hierarchy of caste the level of purity is decreased from the top level to bottom. Along with the level of purity the level of power is closely related with the caste hierarchy therefore B.R Ambedkar by arguing said that caste is a system of 'graded inequality in which castes are arranged according to an ascending scale of reverence and a descending scale of contempt' (Chakravarti, 2013). In other words if we enter in the hierarchy of the caste system then we will find that power, social status and level of purity of the group of people who are at the top position is very high. Similarly we will find that the level of purity, power and social status of the group of people who at the bottom of the caste hierarchy is very less and hence they are regarded as the dirty and polluting. Thus caste can be analysed from the perspective of opposition between the ideologies of pure and impure or pollution as Louise Dumont did through his prominent book 'Homo Hierarchicus' published in 1966. According to him purity is responsible for the inherent hierarchy of traditional Indian society and therefore it is ideological rule behind the caste system. He further asserted that caste system is based on the principle of purity, each caste of Indian society is located in the caste hierarchy on the basis of the purity and the higher level of purity implies higher caste (Olivelle, 1998).

In the caste society the level of purity is preserved through the institution of caste. Therefore it can be said that caste and purity are intertwine in nature. It is believed in the caste society that by the touch of the low caste person, inter-marry and inter-dining between different castes make the higher caste people impure or polluted. Therefore it is seen that the higher caste people always make distance from the low caste people. Similarly rules and regulations are imposed on the low caste people so that they could not come in the contact of the high caste people. For example low caste people were restricted to take water from the same wall from where the high caste people take water, the low caste people are prohibited to the temple where the high caste people take the name of god. Uma Chakravarti in her book argued that in Kerela, traditionally the lower caste people need to maintain a minimum distance from the high caste people so that the former could not pollute the latter. Further she mentioned that even if the shadow of the lower caste people fall on the Brahmin then it is a cause of making the Brahmin an impure one (Chakravarti, 2013). Moreover, untouchable are avoided by the high caste people because they are regarded as the cause of pollution by their touch. If an untouchable touch a high caste person then by observing purification ceremony, that high caste person need to become pure (Rodgigues, 2017). Similarly, in the Assamese society also it is seen that the Goosain or Bamun (high caste people) do not take any goods from the hand of the lower caste people such as Koivarta (Borpujari, 1994). Therefore, the people of caste society are seen as very much concern to maintain their purity. In this regard the caste system helps the people to maintain their purity because caste compartmentalised the people into various groups according to the level of their purity. Moreover the caste system helps to identify the people's caste as people follows certain kind of code and conduct according to their caste. For instance earlier in the forehead of the sudras a broom was tattooed to identify that they are belongs from the lower caste and thus the high caste people make distance from them through the identification mark i.e. the broom so that they could save themselves from the apprehension of being polluted. Therefore it can be said that the ideology of 'purity and impurity or pollution' is closely related to the caste system and caste system is the protection of the purity of the residents of a caste society. 
Caste shares an organic relationship with gender. Caste can't be reproduced in the absence of gender. The pattern of marriage, sexuality and reproduction are the fundamental elements of the caste system. Without these elements caste system would be stagnant or collapsed. Because without endogamy caste system could not be maintained or ensure for the next generation. As endogamy is the avenue to the caste system hence sexual control is obvious in this regard. Thus gender subordination is closely linked with the caste system. The Hindu caste society (bounded group of people) always tries to maintain its distinctiveness from the other. Therefore it is the endogamous i.e. marriage within the same group of people marriage system that helps to exclude other group of people from a particular group of people (Chakravarti, 2013). Thus from the very beginning of the process of gender socialization it is teach to the children to make distance from the other caste's people. Children are taught to avoid making any personal relation such as love and marriage. The principle of endogamy is hegemonized among the member of caste society. Moreover it is seen to impose the endogamy in coercive means who try to violate this norm. In this context it is proved that in the patriarchal Hindu caste society, women's sexuality is controlled more strictly. Because in endogamy female sexuality is considered as the key to maintain the distinctive characteristics of a bounded group of people and from this time women sexuality is controlled by the society. For instance pre-puberty marriage was legitimised in the Brahmin society and it is the parents who arrange their children's marriage so that they could not marry a person out of his/her caste. Moreover it is written in the brahminical literatures that a pure womb or sexuality of the girl is the property of her husband so it is the responsibility of the parents that their girl should married off before her first menstruation. Therefore it can be argued that in the caste society especially among the Brahmin the consent of the girl is nullified in her marriage. Moreover the pre-puberty marriage is one of the reasons of the sufferings of early widowhood of the Brahmin girl.

In Hindu caste society it is believe that the purity of the caste is always related to the purity of women. The purity of woman ensures the caste purity. Thus the member of caste society always tries to maintain the purity of women both before and after their marriage. In Hindu society marriage can be translated as 'Kanyadaan'. Kanyadaan implies the activity of gifting girl to a man. But here the concept of virginity is associated with the activity of Kanyadaan. The actual meaning of Kanyadaan is gift of virgin woman to a man (Chakravarti, 2013). The woman who loses her virginity before her marriage is regarded as impure. Therefore such women are not suitable for Kanyadaan. Because an impure woman could pollute the other family members of her husband and ultimately the society. Therefore the women's sexuality is strictly controlled before her marriage by their father. Similarly after the marriage women's sexuality is controlled by the husband and in their widowhood to the end of their life, their sexuality is strictly controlled by the family and society so that their caste purity could be ensured, which is dealt in the third chapter of this dissertation.

The name of caste is always related with the religion of Hinduism. In other word caste is the peculiar characteristic of Hindu society. Hindu dominated country like in Nepal it is seen that the caste prejudice is omnipresent in their society. Before the Maoist's war in Nepal, the Nepalee society was relatively more patriarchal in terms of caste. The Maoist fought against the inherited inequality of the Nepalee society based on caste, gender and ethnicity along with the aim of freeing the country from monarchy. As the Nepalee society is very much caste ridden therefore it is seen that the society is more concern on the notion of purity of women. Inter-caste marriage is rare incident in Nepal. But during the Maoist war it was seen the marriage of the high caste girl who loved low caste boy, who joined in the war. Because the Maoist did not consider the caste or any inequality based on primordial believes. Women are controlled by treating as impure during their menstruation or the time of giving birth of the children. During menstruation they women need to stay away from their family members so 
that their touch could not pollute the family members. The women were made excluded for seven days during their menstruation. Similarly, the women who gives birth to the children, they are treated as impure and no one touches them in the apprehension of being polluted, From the very time of giving birth of the children to next nine days the mothers are regarded as impure. They are restricted to come out from the four wall of the house so that the impure mother could not touch other. In such situation they need to do everything for themselves. Therefore in the name of caste women are controlled strictly (Nightingale, 2011).

Like the Nepalee society, in the caste ridden Assamese society the notion of women's purity is a matter of concern for the caste purity. In the Asamese also the menstruating blood is regarded as the impure or a reason of pollution. Therefore during the menstruation the Assamese women are kept separate from the other family member so that her touch could not pollute other pure family member. If someone touches her in such time, he/she need to take bath. It is seen in the Assamese society that no one can touch the menstruating woman to three days from the very day of menstruation. Though after three days she can touch the family member or other goods of the house but she is restricted to enter into the kitchen, Gossain ghar and religious institutions such as Namghar and Satra. The menstruating Assamese women are regarded as touchable after observation of the ritual of Suwa Kheda in the third day of her menstruation. In case of Brahmin society of Assame if someone touch a menstruating woman then he/she need to go through the process of Prayachhitta or purification ritual (Goswami, 2010). On the other hand it is seen that the women who gives birth to the children they are regarded as impure or polluted for ten days. During that time no one can touch them. Therefore it can be said that in the caste society the notion of purity of women is closely linked with the caste purity. To maintain the purity of caste women are controlled because caste purity is associated with the purity of women. Therefore in the time of menstruation or giving birth of the children which are regarded as impure, women are treated as impure and in the apprehension of being polluted the family member or other person don't even touch to them.

Moreover it can be argued that the caste and cultural association lead to the emergence of prostitution which is a form of gender violation. In South India and Orissa, the practice of Devadasi is seen. The Devadasis are female temple dancer. According to this culture nonBrahmin but not untouchable girls are dedicated to the temple as the wife of god. Therefore they don't become widow and remains as the wife of god till the end of their life. Though the Devadasis are the wife of god of a particular temple but the priests that is a Brahmin or the patrons of the temple are their sexual partners. Thus a Devadasi became a sexual slave or prostitute of the upper caste Brahmin. This tradition is exploitative in nature because the Brahmin girls are not dedicated to the temple as Devadasi. It is a particular non-brahmin caste girl that is offered to the temple and thus they became Devdasi or prostitute or sexual slave for the priestly Brahmin caste (Chakravarti, 2013). Thus it can be said that the caste system is closely linked with the issues of gender.

Thus it is seen that in the caste society, the low caste people always suffers from gender or sexual violence. In some part of Bihar, it is evident that the lower caste women like Dalit and Harijan which are treated as untouchable, forced to sleep with the village head man who belong from high castes, of their village in the first night of their marriage. Here it is notable that the attitude or caste aversion of the high caste people towards the low caste people or low caste women automatically vanished when the question of sexual pleasure comes in front of them (Anne Mrudula, 2013). In this way the caste intersectionality on gender operates in the caste society where the lower caste people always seen as victim.

In the light of above discussion it can be argued that we can't analyse the caste system by separately from its relatives. People are seen to be confused while they use the word caste 
interchangeably with the terms 'Varna'and 'jati'. But we can't interchangeably use these two terms to refer the caste system because castes are the constituent element of a particular Varna. Apart from these, caste has its close relation with the endogamous marriage principle, the ideology of 'purity and impurity or pollution', division of labour, gender, culture, punishment and various socio-political institutions.

\section{REFERENCES}

[1] Abraham, J. (2014). Contingent Caste Endogamy and Patriarchy Lesson for ur Understanding of Caste. Economc and Political Wekly, vol.XLIX, No.2 , 56-65.

[2] Anne Mrudula, J. C. (2013). Gender nd Caste Intersectionality in the Indian Context. 31-48.

[3] Awasthi, Deepa. (Ed.). (2016). Khap Panchyat, Women and Honour Killing. Kalpaz Publications. Delhi.

[4] Ambedkar, B.R. (2017). Annihilation of Caste. in Valerian Rodrigues (ed.). The Essential Writings of B.R. Ambedkar, New Delhi: Oxford University Press.

[5] Beteille, A. (1996). Varna and Jati. Sociological Bulletin, 45(1), 15-27.

[6] Borpujari, H. (1994). American Missionaries and The Nineteeth Century Assam. Jorhat: Assam Sahitya Sabha.

[7] Chakravarti, U. (2013). Gendering Caste Through a Feminist Lens. Calcutta: Stree.

[8] Chakravarti, Uma. (1993). Conceptualizing Brahminical Patriarchy in Early India: Gender, Caste, Class and State. Economic and Political Weekly, Vol.28, No.14, 579-585.

[9] Dumant, Louis. (1989). Homo Hierarchicus: The Caste System and Its Implications. Oxford University Press: Delhi.

[10] Das, Mitoo. (2008). Menstruation as Pollution: Taboos in Simlitola, Assam. Indian Anthropologist, Vol.38, No.2, 29-42.

[11] Goswami, M. R. (2010). Dontal Hatir Une Khowa Hawdah. Guwahati: Students Store's.

[12] Guterman, M et al. (2007). Menstrual Taboos among Major Religion. The Internet Journal of World Health and Societal Politics, Vol.5, No.2, 1-7.

[13] Jha, Divyendu and Janya Sharma. (2016). Caste and Prostitution in India: Politics of Shame and of Exclusion. Anthropology, Vol.4, No.1,1-4.

[14] Khan, R. A. (2012). Honour Killing Roots and Remedies a Global View. New Delhi: Mittal Publication.

[15] Komsler, Harold M. (1938). Hebrew Menstrual Taboos. The Journal of American Folklore, Vol.51, No.199, 76-82.

[16] Menon, Nivedita. (2012). Seeing Like a Feminist. Penguin, India.

[17] Nightingale, A. J. (2011). Bounding Difference: Intersectionality and the Material Production Of Gender, Caste, Class and Environment in Nepal. Geoforum 42, 153-162.

[18] Olivelle, P. (1998). Caste and Purity: A Study in the Language of the Dharma Literature. Contribution to Indian Sociology (n.s.) 32,2, 189-216.

[19] Panini, M. (2001). Caste, Race and Human Rights. Economic and Political Weekly, 33443346.

[20] Quigley, D. (1999). The Interpretation of Caste. New Delhi: Oxford University Press.

[21] Rodgigues, V. (2017). The Essential Writings of B.R. Ambedkar. New Delhi: Oxford University Press. 